\title{
UNUSUAL REBUILDING METHOD OF HISTORIC ST MARY'S CATHEDRAL IN THE CAPITAL OF WESTERN AUSTRALIA
}

\author{
Adam WYSOKOWSKI ${ }^{1}$ \\ University of Zielona Gora, Zielona Góra, Poland
}

\begin{abstract}
St Mary's Cathedral is the Archbishop church of the Archdiocese in Perth in Western Australia. The presented sacral building was built in neo-Gothic style during the years 1863-1865. Cathedral was officially dedicated and opened for the service on $29^{\text {th }}$ January, 1865. In 1973 was proclaimed the Marian Sanctuary and now represents one of the largest religious facilities in Perth. In 2005, the city authorities, together with the Archdiocese took a collective decision on the necessity of a comprehensive renovation of this sacred object. The renovation was due to the technical condition and the lack of usability of the object. The author of the paper had the opportunity to experience these problems by visiting this place several times, first time in 1989 and next years. Thus, the renovation of the present Cathedral was in its assumption not only to perform maintenance of the building and its specific architectural elements but also to increase its functional features - usable for the faithful and tourists.

Reconstruction of St Mary's Cathedral in Perth can be a good example increasing the wider functionality of such facilities while keeping their antique and historical qualities. In this paper the above-mentioned issues will be more widely developed by the author.
\end{abstract}

Keywords: cathedral, historical facilities, rebuilding, renovation, functionality.

\footnotetext{
${ }^{1}$ Corresponding author: University of Zielona Gora, Faculty of Civil Engineering, Architectureand Environmental Engineering, Z. Szafrana st 1, 65-516 Zielona Góra, Poland, e-mail: awysokowski@infra-kom.eu, tel.+48683282256
} 


\section{INTRODUCTION}

St Mary's Cathedral, Perth (the capital of Western Australia) - whose official name is "Cathedral of the Immaculate Conception of the Blessed Virgin Mary" is one of the largest religious buildings of the Archdiocese in this city. The present cathedral is located on Victoria Square in the centre of Perth. In the photo placed in Figure 1 one presented a general contemporary view of St Mary's Cathedral in Perth (2014).

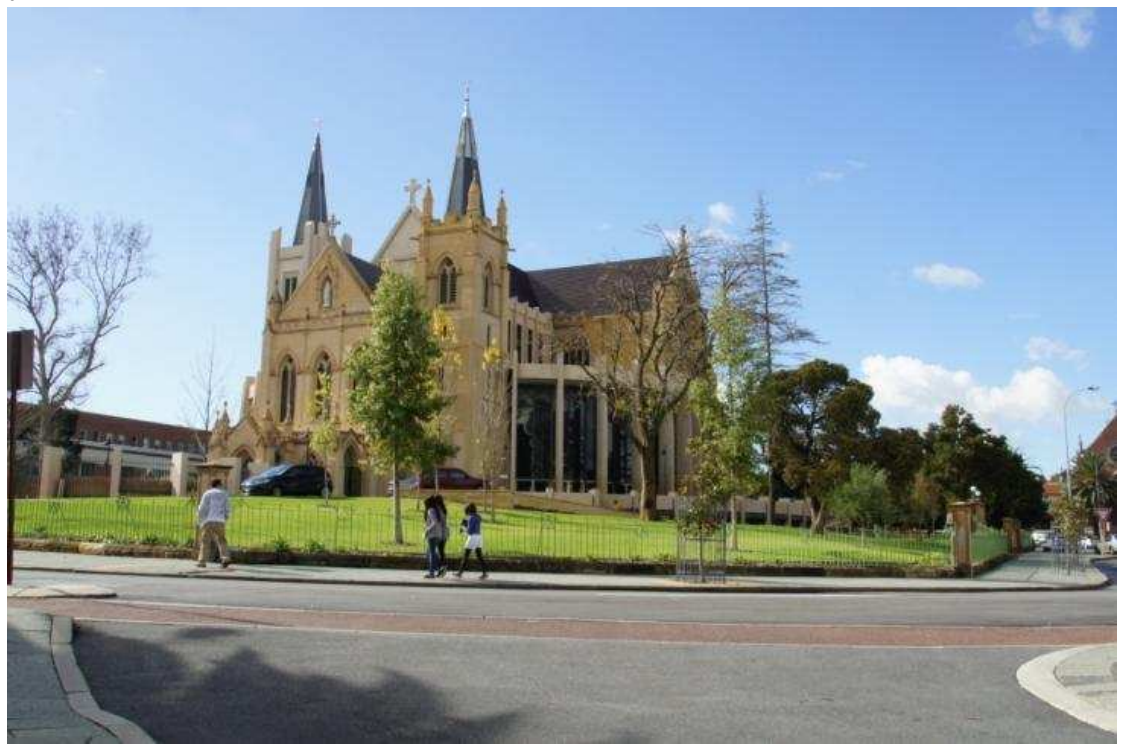

Fig. 1. General view of St Mary's Cathedral in Perth - Western Australia

The property which is the subject of the paper was rebuilt several times to the needs of public utility. The main architectural form of the cathedral building underwent several changes due to subsequent construction works carried out, including years 1865, 1920 and 1973.

However, the most spectacular reconstruction of the Cathedral took place in 2006 and included within its scope not only the renovation of the object, but also improving the functional and operational characteristics that were insufficient. Because of the interesting and the "brave" way of treating the renovation and expansion of this sacred building, the author concluded that this issue is worth presenting. Therefore, this paper discusses the reconstruction assumptions of the object both in terms of works for the comprehensive renovation of the cathedral, as well as to improve the functional and operational characteristics of the building. 


\section{HISTORICAL OUTLINE OF THE CATHEDRAL}

The foundation stone of the Cathedral of the Immaculate Conception of the Blessed Virgin Mary was laid on 8 February, 1863.

The main architect responsible for the construction work was Joseph Ascione originally from Italy. The cathedral was consecrated and opened on 29 January, 1865. Figure 2 shows a view of the sacral building in its original form photography dates back to 1894 .

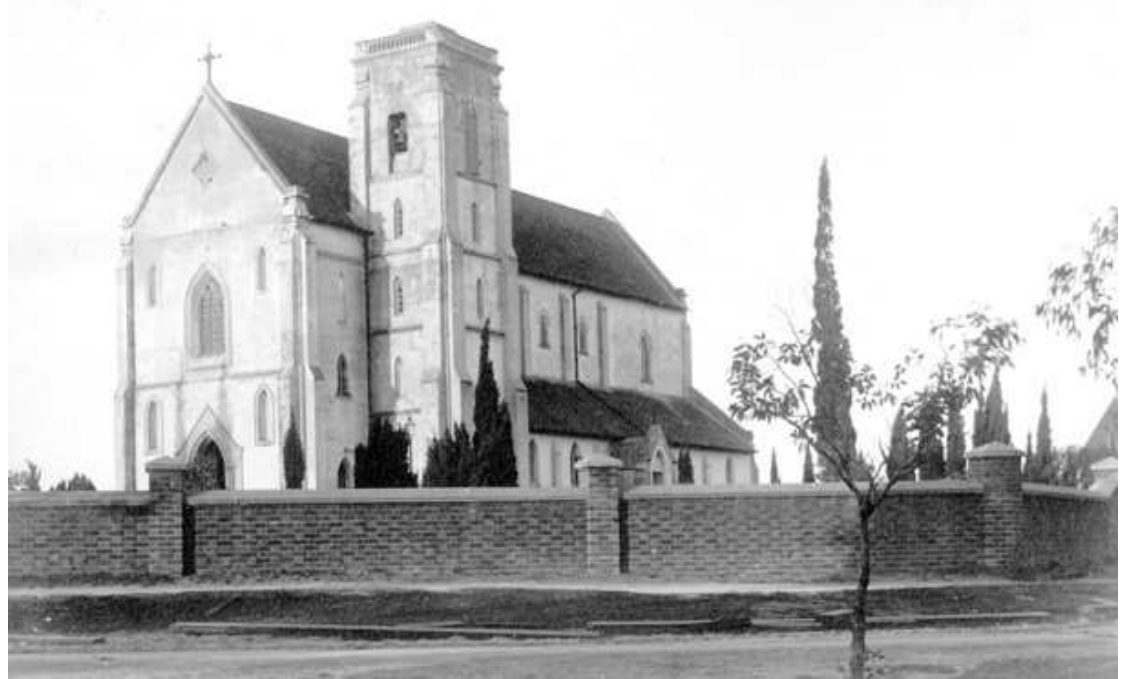

Fig. 2. General view of the sacral building in its original architectural design from 1894.

It was a relatively small building, although at that time it most likely met the needs of residents.

In 1905, the front body of the sanctuary was supplemented by an additional (twin) tower with a spire. Due to the ever increasing needs of the faithful already in 1926 there were plans of a total redesign of the then building. For this purpose, the Archbishop of Perth, decided to build a new cathedral. The original reconstruction plan assumed the preservation of the existing apse and the connection of the main nave with the side ones. The intention of the architects was to preserve the Gothic style in the new church.

On 25th April 1926 even a symbolic cornerstone was built in, but the period of the "Great Depression" [3] and the subsequent Second World War prevented the implementation of these plans.

Liturgical reforms of the Second Vatican Council in 1973 enforced the need to rebuild the interior of the sanctuary. At the request of the then Archbishop Sir 
Lancelot Goody, altar and pulpit in the central part of the cathedral were completely reconstructed [1].

In mid-1999 the Archdiocese announced that it intends to eventually complete the expansion planned since 1926. Starting this investment task was scheduled for 2001. However, there were problems with obtaining adequate funding for the extension, which delayed the start of the project. Finally, after securing sufficient funds for the project cathedral was closed to visitors and the faithful in August 2006 in order to begin its comprehensive reconstruction [2].

\section{RECONSTRUCTION ASSUMPTIONS OF THE CATHEDRAL}

As already mentioned decision of the necessity of comprehensive renovation of this sacred object was due to technical condition and the lack of the required usable functionality of the object. The number of people regularly visiting the cathedral, as well as the tourists continued to rise, causing problems both for the same object, as well as ensuring an adequate number of parking spaces. Especially, as it concerns the central part of the urban area. The author of the paper had the opportunity to experience these problems visiting this place several times in 1989 and subsequent years.

Given the above renovation of the Cathedral had in its assumption not only maintenance work on historic buildings and its specific architectural features, but also increase its functional - performance characteristics for the faithful and tourists. Key assumptions used for improving the functionality of the object were achieved, among others, by:

- increasing the usable area and volume in the interior of the cathedral through its expansion,

- improvement of the chancel illumination, transept and naves bodies,

- construction of sanitary facilities and associated premises,

- replacing the main heating and sanitary installations,

- replacing the electrical system and equipping it with modern electronics,

- improving the throughput of internal routes,

- execution of underground parking in the immediate vicinity of the cathedral, which facilitated the parking of vehicles in the strict central buildings of the city,

- rebuilding of infrastructure within the cathedral (construction avenue for vehicular traffic, bicycle paths, sidewalks, adequate vertical and horizontal marking) and the modernization of the adjacent streets 


\subsection{Reconstruction of the main structure of the object}

The reconstruction plan of the main structure of the building relied in particular on the necessity to enlarge the volume of the object - and therefore the usable space, with the effect of sunlight illuminating the object.

This is achieved by "cutting out the" middle, narrow part of the cathedral with small window openings and constructing at this point double-sided "expand" (i. e. development) of the central part of the cathedral through the construction of two symmetrical aisles of a modern spacious architecture.

An outer load-bearing structure supporting the roof surfaces of the aisles are the pillars of reinforced concrete with a variable section whose architectural form also allows sufficient illumination of the cathedral interior through the use of large panes of glass.

The essential inner structure of these aisles accounted steel frame construction made of structurals. Through the use of steel components one obtained "lightness" of the design and construction elements do not restrict architectural values inside a cathedral.

In the photographs, appearing in Figures 3 and 4 was shown the "effect" in the form of the spaciousness of the cathedral building, achieved through the expansion of its middle part (additional usable space in the aisles and intense lighting).

In addition, in the photographs, appearing in Figures 5 and 6 one shown construction details of load-bearing steel structure inside the sanctuary.

\subsection{Reconstruction of the facility equipment}

As already mentioned, the reconstruction of the object was primarily to improve the function - utility characteristics. As it is generally known, increased usable space of the object is also associated with the need to rebuild its equipment. In that case, it must be based on the relevant guidelines of code.

In the case of the object reconstruction included constructing completely new industrial installations.

In particular, one performed a complex ventilation and heating systems. The method of distribution of exhaust components was designed in order to not to affect the character of the interior, while maintaining their full capacity. This was achieved by using a specially adapted fitting, both in terms of shape and colour. 


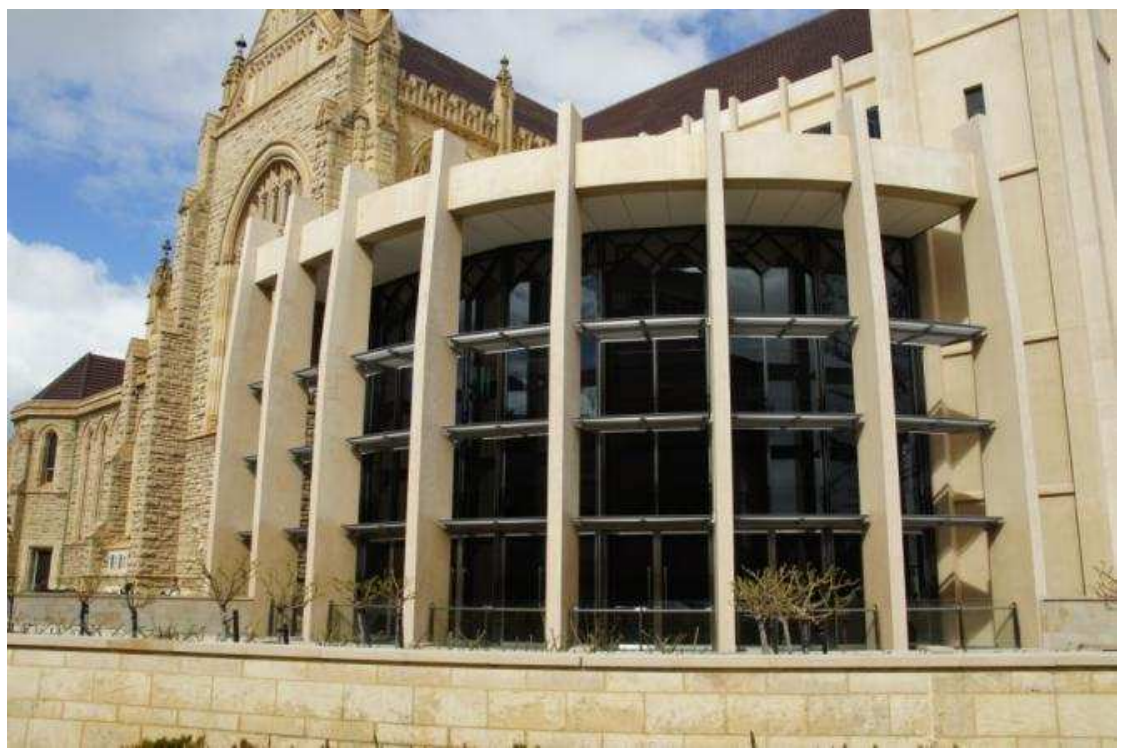

Fig. 3. A general view of one of the attached aisles, aimed at increasing the usable area of the object. Clear way of combining "the new" with "the old" - in the background view of the historic facade of the cathedral

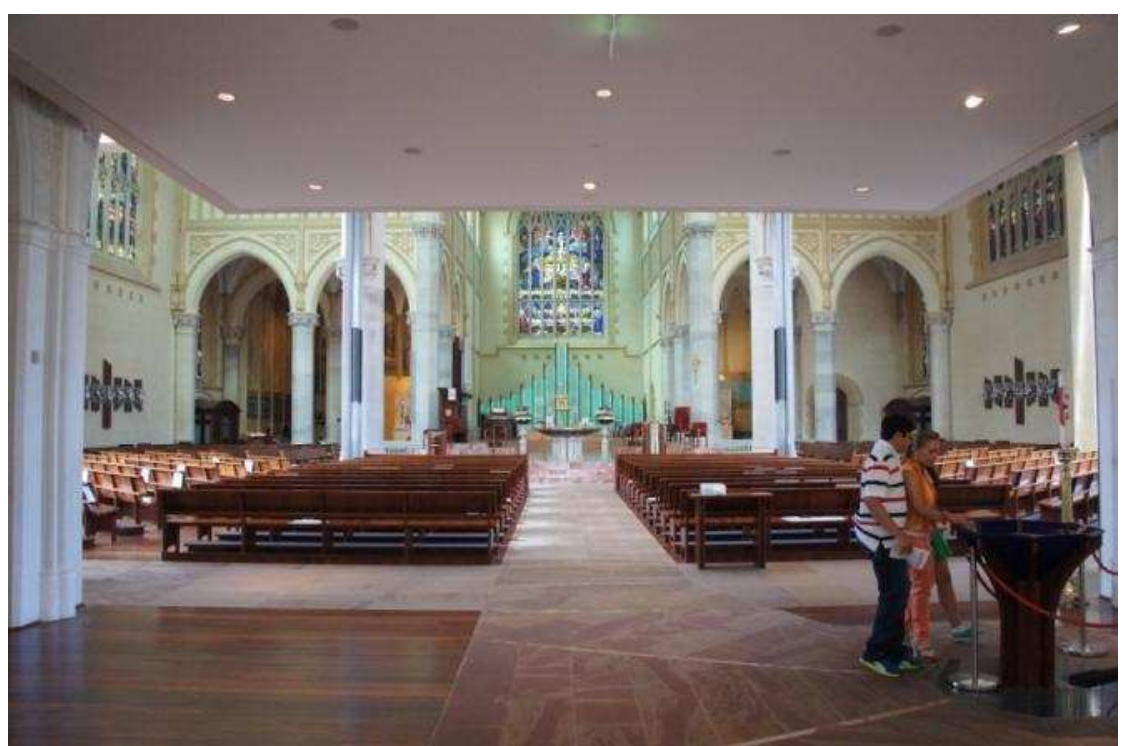

Fig. 4. View of the interior of the cathedral from the entrance. Visible effect of increasing the usable space of the object by mounting double-sided aisles and additional lighting 

IN THE CAPITAL OF WESTERN AUSTRALIA

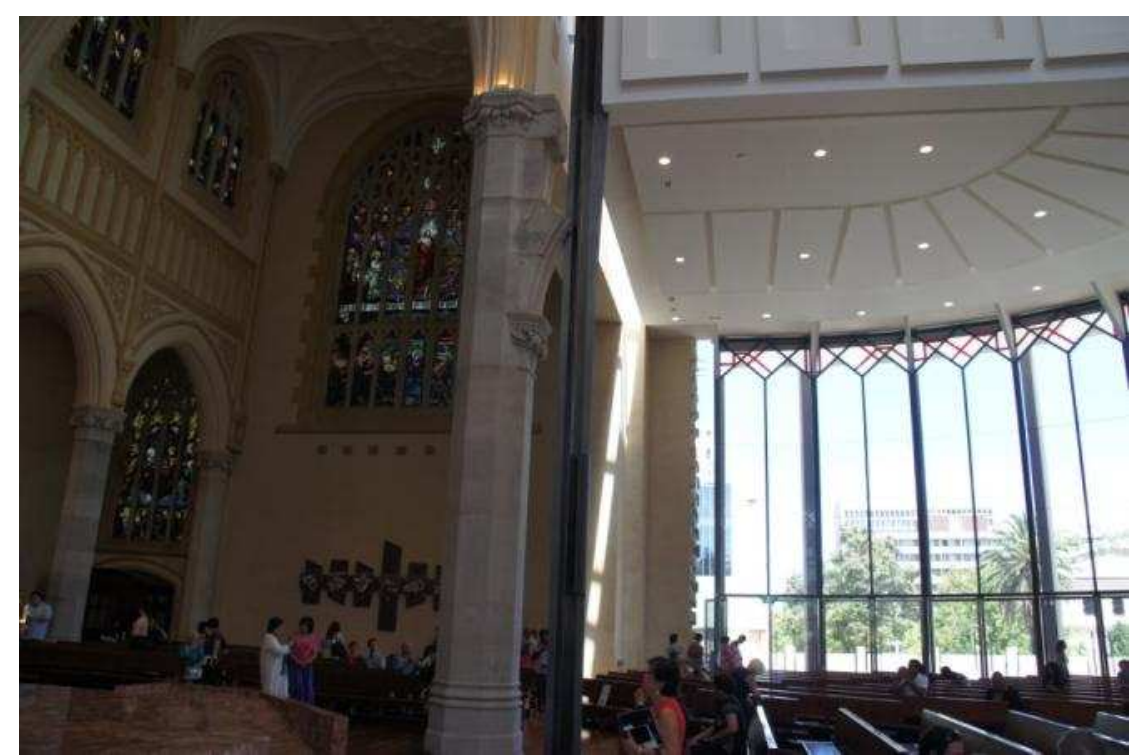

Fig. 5. View of the combining area of the cathedral existing structure with an added aisle. Visible pillar of steel structure next to the historical pillar made of sandstone

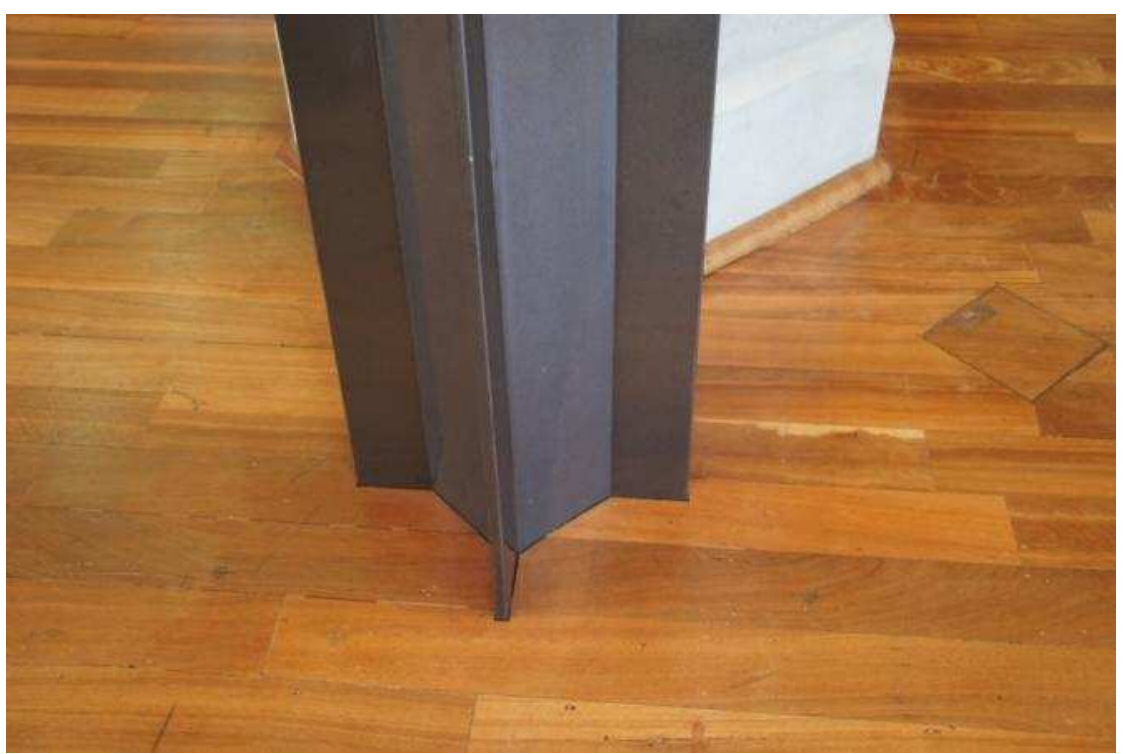

Fig. 6. Zone detail of "penetration" of column base by the design of the floor. Visible special section of the pillar limiting the number of stiffeners (battens and ribs) - in order to eliminate unsightly, in this case, architectural details 
In the photographs, listed in figures 7 and 8 one shown an example of the details of used solutions of heating and ventilation systems.

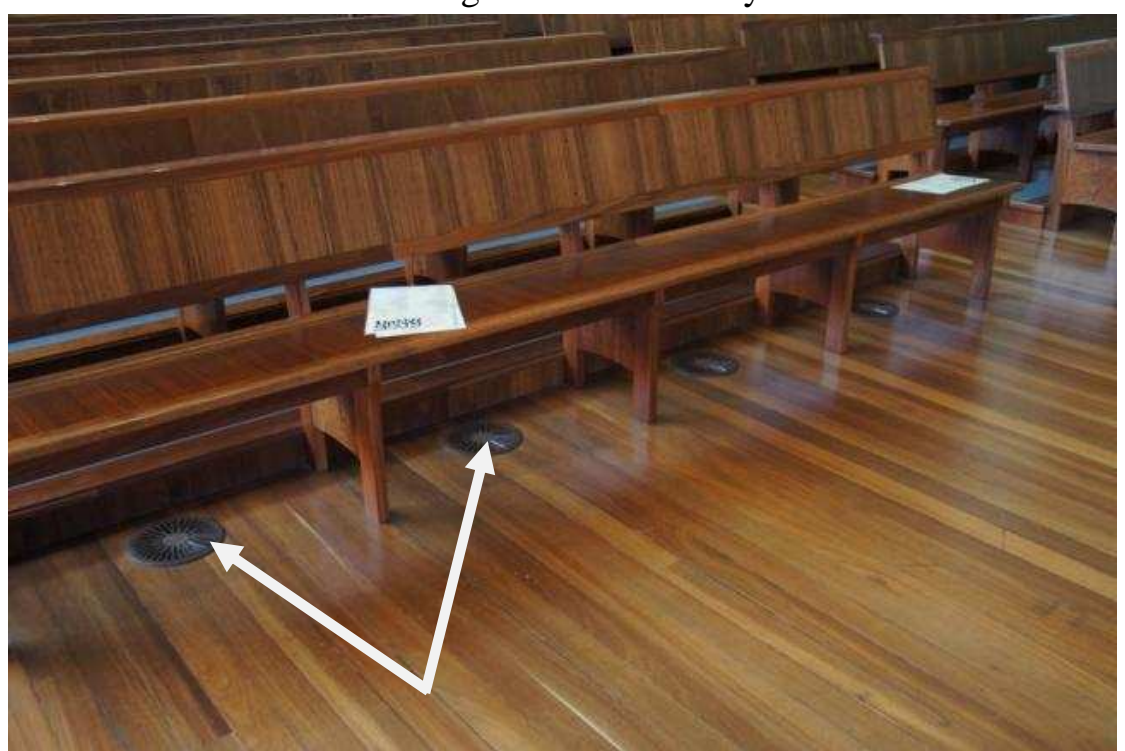

Fig. 7. Way of solving heating system through the use of air supply grilles under the seats of benches

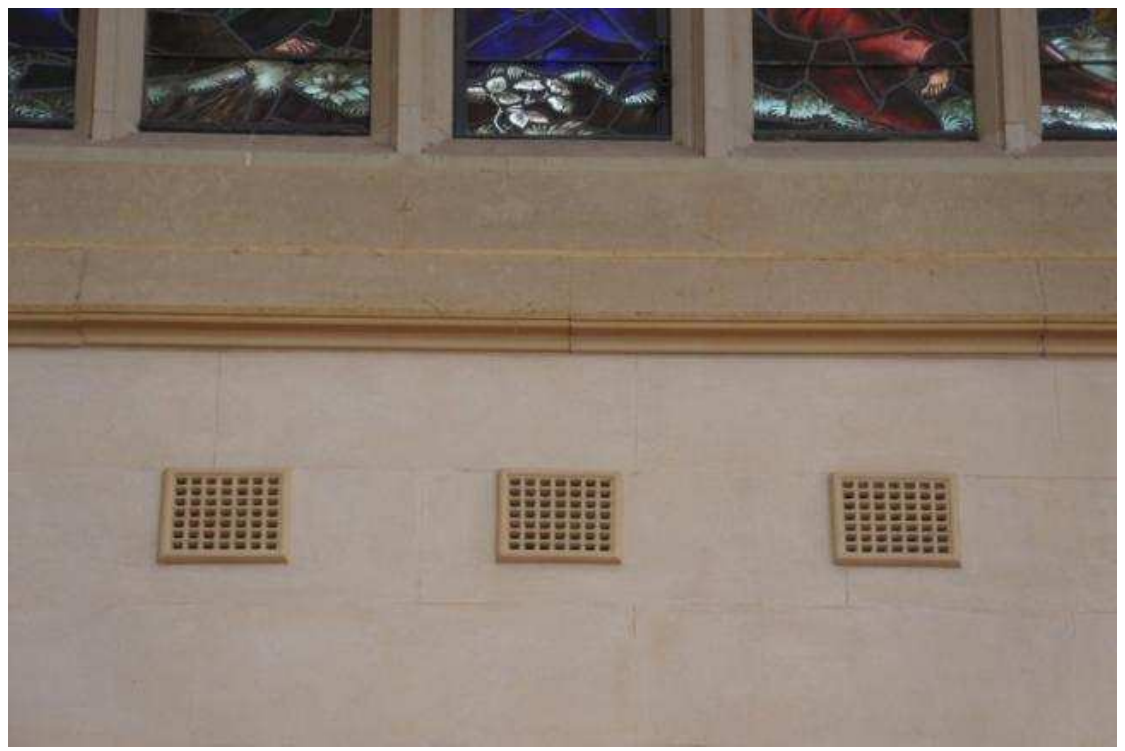

Fig. 8. Detail of the elements of the ventilation system - exhaust grilles. Visible effect of properly chosen elements to the historic character of the cathedral interior 
The whole electrical, electronic including sound equipment and lighting installations have also undergone conversion. Lighting points have been selected in such a way so that to illuminate, as much as possible, the cathedral room.

For lighting up one used modern spotlights "discreetly" integrated in the ceiling areas of the aisles.

The given effect is illustrated by a photograph presented in Figure 9.

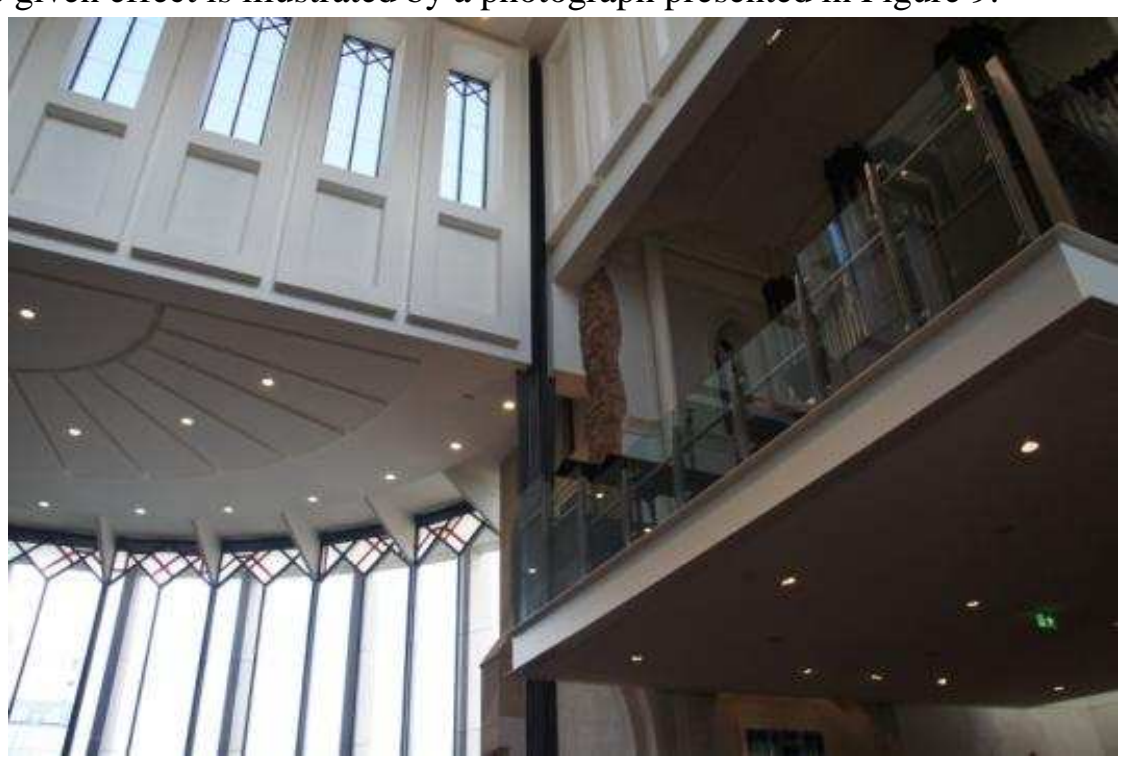

Fig. 9. Detail of lighting elements of the cathedral aisles. Visible "discreet" modern lighting fixtures with high efficiency

As it is well known religious buildings belong to public facilities areas. Therefore, at the design stage of the refurbishment one also provided devices to facilitate movement of people with disabilities both in the interior of the cathedral as well as within it. Elimination of architectural barriers made it easy to navigate especially wheelchair users.

An example to facilitate the use of a sanctuary for disabled and elderly people shows the photograph in Figure 10.

\subsection{Reconstruction of infrastructure and increasing the number of parking spaces}

As already mentioned in the paper, rebuilding the object consisted of not only expansion of the aboveground part. As part of the reconstruction one also built an underground part. There were located, among others, toilets and associated facilities. In order to facilitate the use of the cathedral for motorized people, in 
rebuilding plans one included the construction of additional parking spaces in the form of a full-scale underground car park, situated under the building of the cathedral.

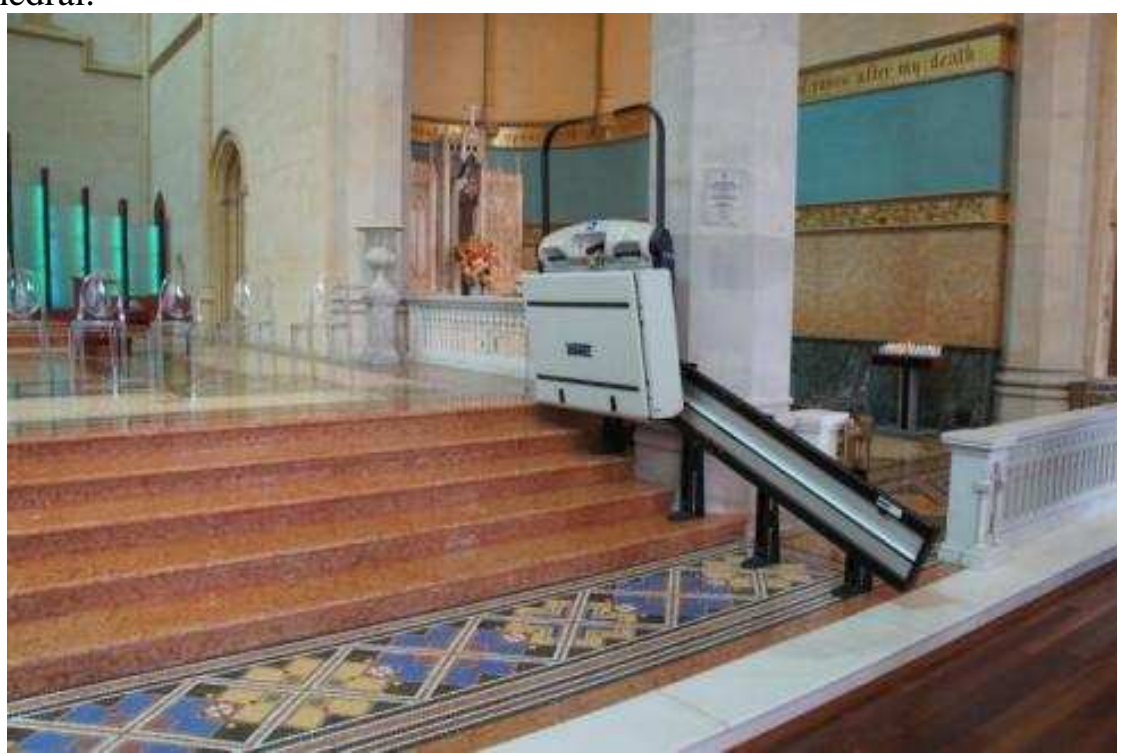

Fig. 10. Example of devices that facilitate the use of sanctuary for disabled and elderly people - ramp that allows overcoming the stairs leading to the altar

It should be noted that the object is located in the centre of Perth, where, as in many modern metropolis, there is a problem with parking the large number of vehicles. The construction of car parks was made, as a typical reinforced concrete skeleton structure.

View of the underground parking located under the building of the cathedral was presented in Figure $11 \mathrm{a}$ and $\mathrm{b}$.

Directly from the underground parking one can go to the cathedral via a network of pedestrian paths (Figure $12 \mathrm{a}$ and $\mathrm{b}$ ).

Of course, in this case one applied technical solutions facilitating the use of a sanctuary for disabled and elderly people, in the form of a gently sloping ramps.

\section{SUMMARY AND CONCLUSIONS}

According to the author, discussed here the rebuilding of St Mary's Cathedral in Perth can be a good example to increase the broadly defined functionality of such facilities while retaining their monumental and historical features. 
a)

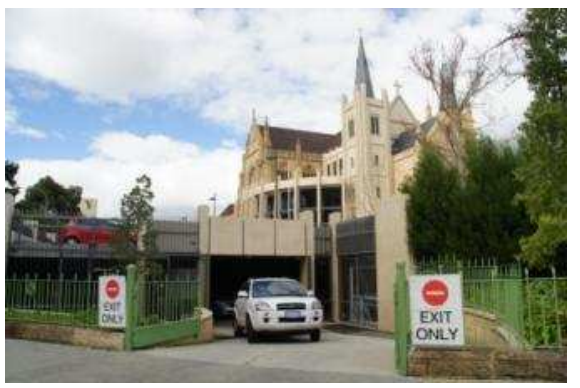

b)

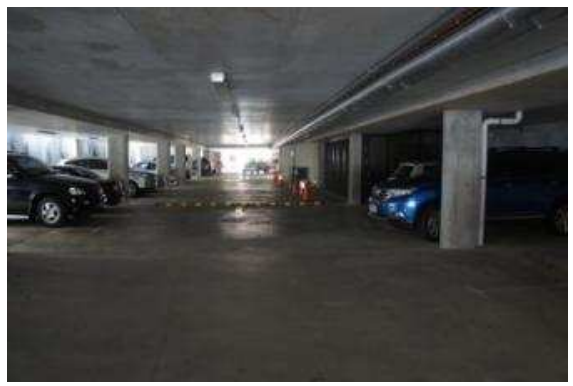

Fig. 11. View of the underground parking located under the building of the cathedral: a) exit from the parking lot, b) view of the underground parking

a)

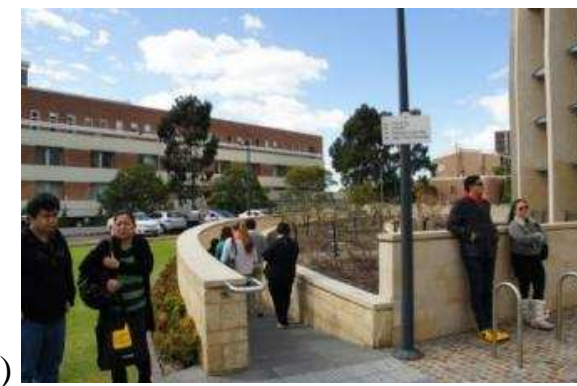

b)

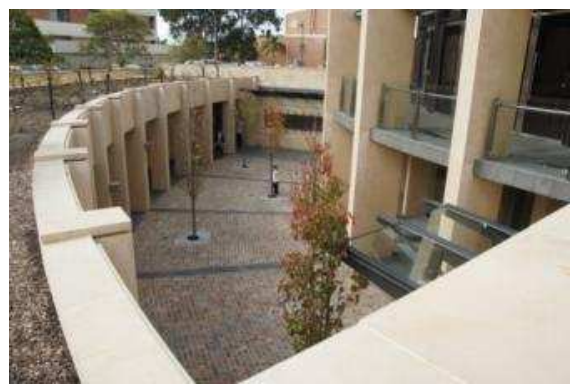

Fig. 12. View of how to connect the underground parking with the building of the cathedral: a) a footpath leading to the parking lot and sanitary facilities, b) view of the parking area within one of the aisles of the cathedral

Worth mentioning is the skilful - according to the author - combination of the historic character of the Cathedral with modern urban architecture. This was achieved by a well-known effect of a styles contrast: historical part - modern part [4].

In this case, the architect has shown a great deal of planning courage, at least because of the designed underground parking under the building of this cathedral. In addition, modern interior furnishings have significantly improved its function- utility features without harming the historic interior of the cathedral. Applied design and architecture solutions and architectural detail, according to the author should provide a good model for national investments involving the renovation of historic buildings and sacral objects.

In conclusion, it is worth noting that in the opinion of the author (he had a chance to visit this place several times in recent years, after the reconstruction *), the object has changed positively in a fundamental way, both in terms of aesthetics, functionality and utility. 


\section{REFERENCES}

1. Informacje ze strony internetowej: www.perthcatholic.org.au/about-us. $2015 r$.

2. Informacje ze strony internetowej: www.en.wikipedia.org/wiki/St_Mary's_ Cathedral,_Perth. 2015 r.

3. Wysokowski A. Most na kryzys - Sydney Harbour Bridge. Nowoczesne Budownictwo Inżynieryjne. Nr 7/8, 2009 r. s. 8-11.

4. Wysokowski A. Historia pewnego mostu na australijskich Antypodach „Whiteman Bridge”. Mosty. Nr 6, 2014 r. s. 72-78.

Wszystkie zdjęcia fotograficzne zamieszczone $w$ niniejszym artykule pochodza z prywatnego archiwum autora artykutu.

*) Autor dziękuję Rodzinie i Przyjaciołom z Australii za pomoc w rozwijaniu pasji związanej z budownictwem.

\section{NIETYPOWY SPOSÓB PRZEBUDOWY ZABYTKOWEJ KATEDRY ST MARY W STOLICY ZACHODNIEJ AUSTRALII}

\section{Streszczenie}

Katedra NMP (St Mary's Cathedral) w Perth jest kościołem arcybiskupim archidiecezji Perth w Zachodniej Australii. Przedmiotowy budynek sakralny został zbudowany w stylu neogotyckim w latach 1863-1865. Oficjalnie Katedra została poświęcona i oddana do użytku 29 stycznia 1865 roku. W 1973 została ogłoszona sanktuarium maryjnym i stanowi obecnie jeden z największych obiektów sakralnych w Perth. W 2005 roku władze miasta wraz $\mathrm{z}$ duchowieństwem podjęły wspólną decyzję o konieczności wykonania kompleksowej renowacji tego obiektu sakralnego. Konieczność przebudowy wynikała ze stanu technicznego oraz braku funkcjonalności użytkowej obiektu. Autor referatu miał okazję doświadczyć tych problemów odwiedzając kilkukrotnie to miejsce w 1989 roku.

Tym samym renowacja przedmiotowej Katedry miała w swoim założeniu nie tylko wykonanie prac konserwacyjnych dotyczących budowli oraz poszczególnych jej elementów architektonicznych, ale również podniesienie jej cech funkcjonalno - użytkowych dla wiernych oraz turystów.

Przebudowa Katedry St Mary w Perth może stanowić dobry przykład zwiększenia szeroko pojętej funkcjonalności tego typu obiektów przy zachowaniu ich cech zabytkowych i historycznych.

W niniejszym referacie wymienione wyżej zagadnienia zostały szerzej rozwinięte przez autora. 
UNUSUAL REBUILDING METHOD OF HISTORIC ST MARY'S CATHEDRAL IN THE CAPITAL OF WESTERN AUSTRALIA

Słowa kluczowe: obiekt sakralny, rewitalizacja, przebudowa, funkcjonalność, cechy techniczno-użytkowe.

Editor received the manuscript: 25.04.2016 